\title{
EXPERIENGE WITH GLACIER CALVING AND AIR-BUBBLING IN HIGH ALPINE WATER RESERVOIRS
}

\author{
By W. Haeberli \\ (Versuchsanstalt für Wasserbau, Hydrologie und Glaziologie, Eidgenössischen, Technischen \\ Hochschule Zürich, CH-8o44 Zürich, Switzerland)
}

\begin{abstract}
Some observations which pertain to the interaction of ice and lake water in a high alpine environment and which were made in recent years in connection with hydroelectric projects and flood protection work are presented. In 1966, when the thin flat snout of Griesgletscher (Walliser Alpen) became submerged during the first filling of a newly constructed reservoir, waves of only very small amplitude were generated by the calving of about $150000 \mathrm{~m}^{3}$ of ice because most of the energy was dissipated by local turbulence. Far more spectacular waves have been experienced near steep ice cliffs in connection with work for flood control. For the design of an air bubbler system, air and water temperatures were measured in winter 1974-75 at Grimselsee, one of the largest reservoirs in the Bernese Alps. These measurements showed that the warmest water at the bottom of the lake was drained away during winter for the production of electricity. A strong temperature inversion forms in the air above the water behind the dam, as the lake level is lowered by several tens of metres.

RÉsumé. Expériences sur des vêlages et des rideaux d'air dans des lacs de retenue alpins. Quelques observations ayant trait à l'interaction entre la glace et l'eau des lacs dans un environnement haut alpin sont décrites. Ces observations ont été faites pendant les dernières années en relation avec des projets d'aménagements hydroélectriques et des travaux de protection contre les crues. Au Glacier de Gries (Alpes Valaisannes) des vagues de hauteur relativement faible se sont produites dans le lac de retenue du même nom lors du vêlage de I $50000 \mathrm{~m}^{3}$ de glace en 1966 , la plus grande partie de l'énergie étant dissipée par turbulence locale. Lors de l'observation de certains lacs glaciaires on a constaté des vagues de hauteur bien plus importante. A l'occasion d'un projet de rideau d'air des mesures de la température de l'air et de l'eau ont été effectuées au Lac du Grimsel, un des plus grands lacs artificiels des Alpes Bernoises, pendant l'hiver 1974-75. Il en ressort que les couches d'eau les plus profondes (qui sont également les plus chaudes) disparaissent en hiver lors du turbinage de l'eau, et qu'une forte inversion de température se forme dans l'air se trouvant en arrière du barrage lorsque le niveau du lac s'abaisse.

Zusammenfassung. Erfahrungen mit Kalbungen und mit dem Luftschleierverfahren in hochalpinen Speicherseen. Es werden einige Beobachtungen über die Interaktion von Eis und Seewasser mitgeteilt, die in den letzten Jahren im Zusammenhang mit hydroelektrischen Projekten und mit Arbeiten für den Hochwasserschutz gesammelt wurden. Eine Kalbung von rund 150 ooo $\mathrm{m}^{3}$ Eis in einem Stausee am Griesgletscher (Walliser Alpen) löste nur Wellen geringer Höhe aus, da der grösste Teil der Energie durch lokale Turbulenz umgewandelt wurde. Im Zusammenhang mit der Beobachtung von Gletscherseen wurden in der Nähe von steilen Eisfronten weit eindrucksvollere Wellen beobachtet. Für die Planung eines Luftschleiersystems wurden im Winter 1974-75 am Grimselsee, einem der grossen Speicherseen der Berner Alpen, Messungen der Wasser- und Lufttemperatur durchgeführt. Es zeigte sich dabei, dass die tiefsten (wärmsten) Wasserschichten im Winter für die Stromproduktion abgeführt werden, und dass sich im Stauraum während der winterlichen Wasserspiegelabsenkung eine ausgeprägte Temperaturinversion in der Luft bildet.
\end{abstract}

MANY problems of applied glaciology in the Alps arise because man is living and working in a high alpine environment which is heavily glaciated. Some of these problems concern the interaction of ice and lake water as it concerns flood protection work and the operation and completion of hydroelectric power plants. In this paper some observations relating to this interaction are reported. They were made in recent years by various staff members of our institute.

\section{Calving waves}

Griesgletscher at the head of the Aegina river (Rhonetal, Wallis) is a flat valley glacier which had a surface of $6.3 \mathrm{~km}^{2}$ in $197 \mathrm{I}$ (Kasser and Aellen, 1976) originating at the top of Blinnenhorn (3 $373.8 \mathrm{~m}$ a.s.l.) and ending at an altitude of about $235^{\circ} \mathrm{m}$ a.sl. In I966 its snout became inundated when the water was rising for the first time behind the newlyconstructed dam of a hydroelectric project. Calving was anticipated and precautions were indicated because the wave caused by the calving might splash over the dam. No information on the expected size of the calving waves was available to us at the time, but it was felt that 
there would be ample time for us to gain experience while the water was still at a safe level. Attempts to secure the necessary information on wave amplitudes were made in two ways, with a limnigraph and by using small pieces of wood placed on the ground along two inclined lines from the shore upwards, at elevation intervals of 0.4 to $0.5 \mathrm{~m}$. The boards were numbered and a large wave of more than about $0.5 \mathrm{~m}$ of amplitude would have been noticed from the displacement of one or more boards. It was not possible to use the power company's limnigraph for recording the wave amplitude (the instrument was based in the usual way on pressure measurements near the bottom of the lake) because at large water depths only a fraction of the wave pressure would have been recorded, except in the case of extremely large wavelengths. Therefore a special limnigraph was used, this instrument recorded the level of a float held in place by four guide wires which were installed in front of the vertical wall of the dam before the water started to rise. A perforated metal sheet was fixed to the float about I $\mathrm{m}$ below the water surface in order to suppress or dampen the very short waves caused by wind action. The operation of the limnigraph was hampered by floating ice, but two calvings were recorded before it broke down completely.

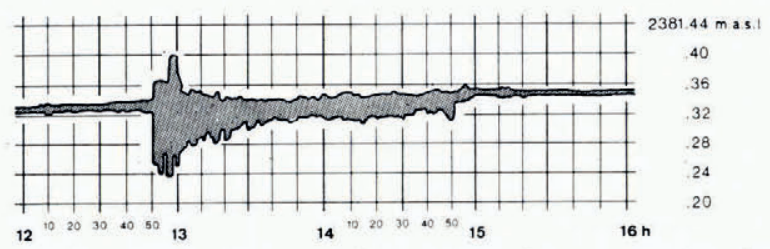

Fig. 1. Drawing of an enlarged section of a limnigraph record showing the calving event at Griesgletscher on 19 September 1966. Calving ice mass: 150 ooo $\mathrm{m}^{3}$; lake surface: 525 ooo $\mathrm{m}^{2}$.

The water reached the edge of the glacier on 2 I June at an altitude of $235^{2} \mathrm{~m}$ a.s.l. From an estimate of buoyancy and strength of the ice wedge becoming gradually submerged as the water started to rise, the calving was expected to occur once a strip of ice some $20-40 \mathrm{~m}$ wide was under water, i.e. at an increase in the water level of about $5^{-10} \mathrm{~m}$. To our astonishment nothing happened until 16 August when the water level had risen more than $20 \mathrm{~m}$ to an elevation of $2373.31 \mathrm{~m}$ a.s.l., and about $170000 \mathrm{~m}^{3}$ of ice had become submerged.

Some model studies were carried out in the laboratory with wedges and plates of wax. These experiments were informative for two reasons. First, the pieces of wax stayed at the bottom of the water for an extended period of time when they were bedded on clay. This observation led to an understanding of why the calving did not take place as expected. The snout of Griesgletscher was lying on fine-grained till (of exceptional stickiness when wet), presumably of such low porosity that it took weeks before the water could penetrate sufficiently to the boundary of ice and ground moraine so that buoyancy could take effect. Furthermore, there is a reasonable chance that the snout was frozen to the ground at its rim where the ice was thin enough for the winter cold wave to penetrate. Secondly, experiments showed that thin wedges or slabs of wax rose to the surface very slowly indeed causing only minor waves but very strong turbulence in the water. Before discovering this effective energy dissipation we had expected the ice to rise above the water-line, fall back, and produce large waves. Based on the results of the experiments, a maximum wave height of about $\mathrm{I} \mathrm{m}$ was expected for the main calving event of Griesgletscher. When the lake was full, such a wave would have produced a maximum discharge of up to $30 \mathrm{~m}^{3} \mathrm{~s}^{-1}$ at the high-water overflow. To avoid such a flood it was proposed to fill the lake up to $2385.50 \mathrm{~m}$ a.s.l., I $\mathrm{m}$ below the overflow level only. This restriction became unnecessary as the facts appeared (compare the pictures given by Kasser ( 1967$)$ ). 
A first ice mass of about 3000 to $4000 \mathrm{~m}^{3}$ calved during the morning of 16 August. The height of the wave produced by this minor event was estimated at $\pm 50 \mathrm{~mm}$ at the limnigraph. The main calving event occurred at noon on ig September, when the lake water level was at $238 \mathrm{I} .33 \mathrm{~m}$ a.s.l. and about $300000 \mathrm{~m}^{3}$ of ice were submerged. No large wave was noticeable. The limnigraph recording (Fig. I) showed amplitudes of $+65 \mathrm{~mm}$ and $-95 \mathrm{~mm}$ only, but it took about two hours for the wave activity to decay. The lake level dropped by about $30 \mathrm{~mm}$, in rough agreement with the volume of ice estimated at $150000 \mathrm{~m}^{3} \mathrm{from}$ its dimensions $\left(\right.$ area $=\mathrm{I} 60 \times 120 \mathrm{~m}^{2}$, mean thickness about $8 \mathrm{~m}$, area of the lake $=525000 \mathrm{~m}^{2}$ ) having changed from the submerged to the floating state.

Disproportionately larger waves than those discussed above form when ice masses break from steep ice cliffs undercut by lake water. During six years of observation (1908-13) a maximum height of $4.85 \mathrm{~m}$ above the lake surface was noted on a calving-induced wave at the Märjelensee (Aletschgletscher) by Lütschg (I9I5). This event happened on 22 October I 908 , when the ice cliff of the Aletschgletscher was about $70 \mathrm{~m}$ high and the lake had a maximum depth of about $40 \mathrm{~m}$. The wave height was measured at a distance of about $400 \mathrm{~m}$ from the ice cliff. From limnigraph observations at the Steinletschersee, about $500 \mathrm{~m}$ from the snout of Steingletscher (Sustenpass, Urner Alpen), during the years i956-6o, Haefeli noted a maximum height of calving-induced waves of about $0.5 \mathrm{~m}$. The ice cliff had a maximum height of about $10-20 \mathrm{~m}$ and the maximum depth of the lake was about $20 \mathrm{~m}$ during this period (Haefeli, I963). In recent years, problems have been caused by repeated calving in a marginal lake of Grubengletscher (Saas Balen, Wallis), a partially cold glacier frozen to the bed at the edge (Haeberli, I976). After two outbursts of the lake (Röthlisberger, 197 I, 1974), a tunnel was driven through part of the glacier tongue and a corrugated steel pipe with a diameter of $1.25 \mathrm{~m}$ was installed in the ground moraine to regulate the lake level. A $21 \mathrm{~m}$ long pipe segment was laid in a ditch, without cover, on a flat stretch of ground alongside the lake shore, so that the pipe entrance would be far enough away from the heavy snow drifts forming regularly at the tunnel entrance. In the summer of 1973 this pipe segment was ripped out of the ditch and deposited $3 \mathrm{~m}$ higher above the shore by a calving wave. It was estimated that about $5000 \mathrm{~m}^{3}$ of ice had broken off from an ice cliff about $25 \mathrm{~m}$ high into the lake at a distance of $60-100 \mathrm{~m}$ from the pipe. During the re-installation of this pipe segment, a survey of the calving activity at the glacier margin was carried out (Haeberli, I975). One detached mass of about $3000 \mathrm{~m}^{3}$ was observed in detail. In 1975 measurements were made of the movement of another ice mass before breaking off (the volume of this mass was about $4000 \mathrm{~m}^{3}$ ) (Haeberli and Röthlisberger, 1976). It was observed that

(I) in both cases the velocity plotted against time followed a curve resembling a hyperbola, in accordance with previous experience from other large ice masses (Röthlisberger, 1974; Flotron, I977; Iken, 1977);

(2) the two curves of velocity against time for the independent events of 1974 and I975 showed a strikingly similar form;

(3) short-interval measurements together with direct (acoustic) evidence suggested that the observed hyperbola-like curve results from a series of cracks forming at a continuously increasing rate;

(4) extrapolation of this curve may permit a short-term forecast of a calving event, as was possible in 1974 .

The calving in 1974 triggered a wave about $\mathrm{I} \mathrm{m}$ high with a wavelength of more than $60 \mathrm{~m}$ (or probably more than $\mathrm{r}$ oo $\mathrm{m}$ ). The maximum depth of the lake was about $\mathrm{ro} \mathrm{m}$ and the velocity of propagation of the first wave was of the order of 7-10 $\mathrm{m} \mathrm{s}^{-1}$. The process of breaking-off and crack formation preceding calving will be studied by seismo-acoustic methods at Grubengletscher. The activity of the ice cliff, which has undergone a retreat of 
about $40 \mathrm{~m}$ from 1970 to 1974 , will also be observed, because of the possibility of a new outburst of the lake.

The studies at Aletschgletscher (Märjelensee), Steingletscher, and Grubengletscher were all carried out in connection with flood protection work, i.e. the investigation of lakes which have produced outbursts (Lütschg, I915; Haefeli, I963; Haeberli and Röthlisberger, 1976). Unlike the rather minor effects of calving-induced wave formation in these cases, snow and ice avalanches into lakes and water reservoirs may constitute serious dangers. Fresacher (I935) describes an ice avalanche at the Hochalm-Kees (Austrian Alps), which triggered the outburst of a proglacial lake with serious damage in the Maltatal. Several model studies of this problem have been undertaken in our institute in recent years (Huber, 1975; Volkart, 1974, I975).

\section{Air bubbling to SUPPREsS ice Formation}

In connection with the construction of the pump storage project of Grimselsee and Oberaarsee, two large water reservoirs in the Swiss Alps (Zingg, I974), a combined water inlet-outlet structure will be placed on the bottom of Grimselsee. To avoid large water losses, and thus energy losses, during construction work on the lake bottom in summer (the period of maximum inflow of melt water from the surrounding glaciers), the inlet-outlet structure will be erected on a float. During the early winter of 1976 the float will be brought to the site of subsequent emplacement. During the winter of $1976-77$ the float will sink as the lake water level drops through normal energy production, and the inlet-outlet structure will be fitted on the lake bottom to the mouth of the tunnel connecting the two lakes. The refilling of Grimselsee can then start with only a little delay. At that time of the year the lake is usually covered by a thick ice cover and navigation is impossible. The area around the float must therefore be kept free of ice to prevent major displacements of the float by the ice cover on the lake shifting with the lowering of the lake level during the winter. Horizontal displacement of the ice cover may be more than $\mathrm{I} \mathrm{cm} \mathrm{d}^{-1}$ (private communication from A. Flotron). Water and air temperatures were measured for the purpose of collecting basic environmental data for the design of an air bubbling system to suppress ice formation near the float. Lakeice cover characteristics were observed during the winter of $1974^{-75}$ on the Grimselsee. The results of these observations show some aspects of air-bubbler design and use in high alpine water reservoirs not usually quoted in the literature (e.g. Williams, I96r ; Ashton, r 974).

It is essential to know water temperatures in order to calculate the heat storage existing in the water body considered. It is well known that water temperatures are not the same every year and are often not at the temperature value for maximum water density $\left(4^{\circ} \mathrm{C}\right)$ (Williams, I96r ; Ashton, I974). At Grimselsee the measurements were made with a thermistor chain at almost equal time intervals. The thermistors (with an accuracy of $\pm 0 . \mathrm{I}^{\circ} \mathrm{C}$ ) were spaced closer to each other near the top than at greater depth in order to identify as accurately as possible the uppermost zone showing the strongest changes in temperature gradient. In Figure 2 water temperatures within the lake are shown for the five consecutive measurements made during winter $1974^{-75}$. It is easily seen that the heat content of the lake is greatly reduced towards the end of winter, because the lowest and warmest water is drained off for the production of electricity. At the end of April, when melt water from the surrounding glaciers and snow fields is starting to flow into the lake, only about $20 \mathrm{~m}$ of water with a temperature of $0.4^{\circ} \mathrm{C}$ is still present.

It was already known that, because of heavy snow accumulation, the ice cover of Grimselsee consists of a combination of snow, slush and ice rather than of clear ice. At the weather station on the dam of Grimselsee (the so-called "Nollen", a rock spur which separates two sections of the dam), total snow depth amounted to 6.02 m on I I April 1975. The ice cover thickness was measured in a bore hole made first by a hand-operated mechanical ice drill and 


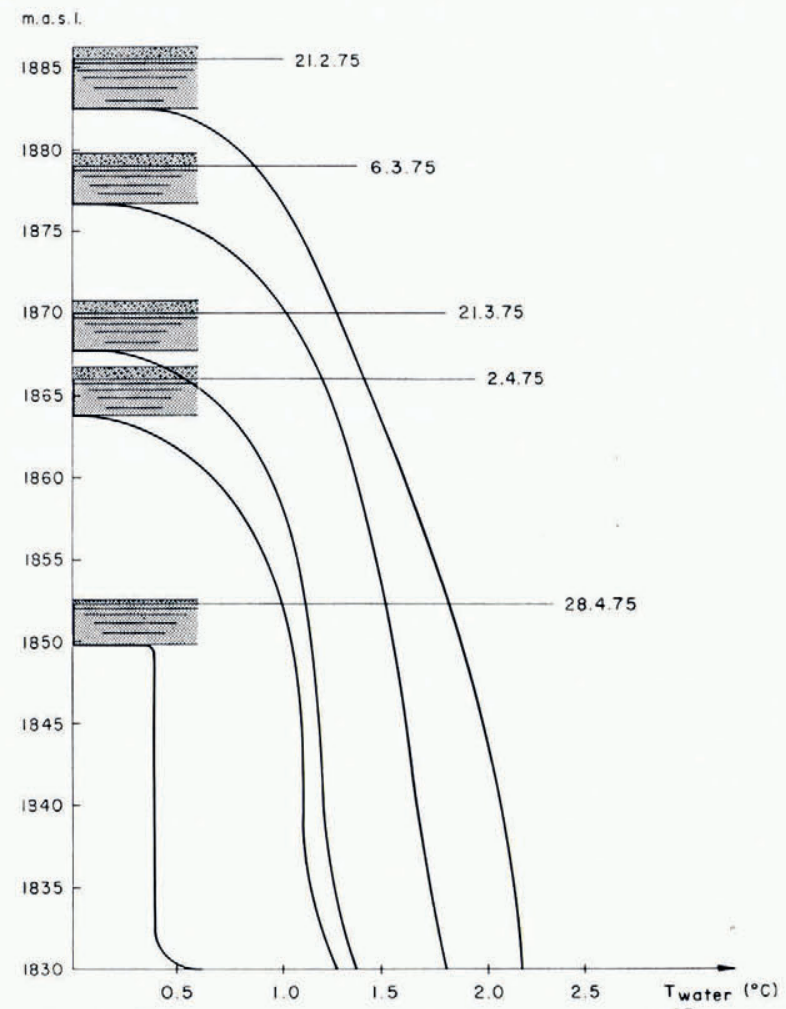

Fig. 2. Water temperature within the Grimselsee reservoir during winter 1974-75. Dates of measurement are given at the water level in the ice cover.

later by a rammsonde. In this bore hole the lake water level within the lake-ice cover was observed too. The density of the snow above the water level was estimated to be $0.2 \mathrm{Mg} \mathrm{m}^{-3}$ before, and $0.5 \mathrm{Mg} \mathrm{m}^{-3}$ after melting had occurred. Density values of the entire ice cover and of its part beneath the water level were calculated by simple proportions. The slush beneath the water level seems to have an average density of about $0.92-0.95 \mathrm{Mg} \mathrm{m}^{-3}$ and therefore consists of nearly $50 \%$ water. Thin ice layers form at the water level, where the slush is in contact with the cold snow above.

Air temperature was measured in a screen fixed on a small float resting on the ice cover on the lake and simultaneously at the meteorological station near the dam. Averaged over the whole period of observations (7I days from 22 February to 20 May with short interruptions) the daily mean of the air temperature at Grimselsee was $5.5^{\circ} \mathrm{C}$ lower than at "Nollen". Thus, a strong temperature inversion forms in the air as the lake level is lowered several tens of metres below the dam during winter. (The height of the screen above the "surface" was not constant because the float carrying the screen became slowly embedded in the lake ice during the period of observation. Absolute temperature values are therefore not very accurate.) Another observation, however, confirmed the presence of a strong and fairly continuous air temperature inversion within the lake basin during winter. The temperatures within the uppermost $300 \mathrm{~mm}$ of the snow cover above water level were at least as cold as those measured during the same period at Weissfluhjoch at an elevation $700 \mathrm{~m}$ higher. From a simple comparison of snow temperatures at Grimselsee and several snow observation stations in Switzerland, the "equivalent elevation" of Grimselsee was graphically deduced. Using an 
average for the air temperature gradient during the winter taken from different meteorological stations in the Alps it could be estimated that the mean air temperature in February at Grimselsee is about $-10^{\circ} \mathrm{C}$ or about $4-5^{\circ} \mathrm{C}$ less than at "Nollen". This simple comparison shows that temperatures in the uppermost layers of the alpine snow cover may possibly be used for a rough estimate of the values of mean air temperature at a given point.

\section{Acknowledgements}

The author would like to express his thanks to Professor P. Kasser, Dr H. Röthlisberger, and $\mathrm{H}$. Siegenthaler for advice and for making available to him the unpublished notes and data on the Griesgletscher calving waves. Further thanks are due to Kraftwerke Aegina A.G., Kraftwerke Oberhasli A.G. and Ingenieurunternehmung Bern A.G. for their support during investigations which were carried on in the course of consultancy work on their behalf.

\section{REFERENGES}

Ashton, G. D. 1974. Air bubbler systems to suppress ice. U.S. Cold Regions Research and Engineering Laboratory Special Report 210.

Flotron, A. 1977. Movement studies on a hanging glacier in relation with an ice avalanche. Fournal of Glaciology, Vol. 19, No. 81, p. 671-72. [Abstract. Full paper in preparation.]

Fresacher, W. 1935. Ostalpengletscher 1933. Berichte über die Gletschermessungen und -beobachtungen des Deutschen und Österreichischen Alpenvereins in den Ostalpen im Jahre 1933. Ankogel-Hochalmspitzgruppe. Zeitschrift für Gletscherkunde, Bd. 22, p. 21 1-13.

Haeberli, W. 1975. Überwachung von Kalbungsflutwellen am Grubengletscher. Schweizerische Bauzeitung, 93. Jahrg., Ht. 43, p. 694-96.

Haeberli, W. 1976. Eistemperaturen in den Alpen. Zeitschrift für Gletscherkunde und Glazialgeologie, Bd. 11, Ht. 2, 1975, p. 203-20.

Haeberli, W., and Röthlisberger, H. 1976. Beobachtungen zum Mechanismus und zu den Auswirkungen von Kalbungen am Grubengletscher (Saastal, Schweiz). Zeitschrift für Gletscherkunde und Glazialgeologie, Bd. I1, Ht. 2, 1975, p. $22 \mathrm{I}-28$.

Haefeli, R. ${ }^{1963 . ~ N o t e ~ o n ~ t h e ~ h i s t o r y ~ o f ~ t h e ~ S t e i n g l e t s c h e r ~ l a k e . ~ B u l l e t i n ~ d e ~ l ' A s s o c i a t i o n ~ I n t e r n a t i o n a l e ~ d ' H y d r o l o g i e ~}$ Scientifique, 8e An., No. 2, p. 123-25.

Huber, A. 1975. Schwallwellen in einem See als Folge eines Felssturzes. Modellversuche zur Voraussage der Auswirkung des Absturzes einer Gesteinsmasse in den Walensee. (In Interpraevent 1975, Schutz alpiner Lebensräume, Tagungspublikation, Forschungsgesellschaft für vorbeugende Hochwasserbekämpfung. Innsbruck, Rauch-Druck, Bd. I, p. 241-54.)

Iken, A. I977. Movement of a large ice mass before breaking off. Fournal of Glaciology, Vol. 19, No. 81, p. 595-605.

Kasser, P. 1967. Die Gletscher der Schweizer Alpen 1965-1966. Publikation der Gletscherkommission der Schweizerischen Naturforschenden Gesellschaft $(S \mathcal{N} G), 87$. Bericht.

Kasser, P., and Aellen, M. 1976. Die Gletscher der Schweizer Alpen 1971/72 und 1972/73. Publikation der Gletscherkommission der Schweizerischen.Naturforschenden Gesellschaft (SNG), 93. und 94. Bericht.

Lütschg, O. 1915. Der Märjelensee und seine Abflussverhältnisse. Annalen der Schweizerischen Landeshydrographie, Vol. I.

Röthlisberger, H. 197I. Massnahmen gegen die Ausbrüche eines Gletschersees ob Saas-Balen (Grubengletscher). Schweizerische Bauzeitung, 89. Jahrg., Ht. 40, p. 999-1003.

Röthlisberger, H. 1974. Möglichkeiten und Grenzen der Gletscherüberwachung. Neue Zürcher Zeitung, 29. April 1974, Nr. 196, p. 39-42.

Volkart, P. I974- Modellversuche über die durch Lawinen verursachten Wellenbewegungen im Ausgleichsbecken Ferden im Lötschental. Wasser- und Energiewirtschaft, 1974, Nr. 8-9, p. 286-92.

Volkart, P. 1975. Talsperren - Uberschwappvorgänge infolge Lawinen- und Eisniedergängen in alpinen Staubecken. (In Interpraevent 1975, Schutz alpiner Lebensräume, Tagungspublikation, Forschungsgesellschaft für vorbeugende Hochwasserbekämpfung. Innsbruck, Rauch-Druck, Bd. I, p. 255-70.)

Williams, G. P. 196r. Winter water temperatures and ice prevention by air bubbling. Engineering Journal (Montreal), Vol. 44, No. 3, p. 79-84.

Zingg, F. 1974. Der Weiterausbau der Kraftwerke Oberhasli. Schweizerische Bauzeitung, 92. Jahrg., Ht. 44, p. $1002-05$. 